\title{
Preventing rhesus babies: the Liverpool research and follow up
}

\author{
C A CLARKE \\ Department of Genetics and Microbiology, University of Liverpool
}

Nowadays it is 'new genetics' that is all the rage, but it is useful to remember that in the 1950s (when David Weatherall was my house physician) that there was also novelty; then, however, it was blood groups and diseases, and it was that research that helped to interest clinicians in genetics, because the disorders studied were common ones.

Aird, Fraser Roberts, and Bentall were among the new names, and there was much discussion about carcinoma of the stomach and blood group A, duodenal ulcer and blood group $\mathrm{O}$, and what it could all mean.

At about this time the Liverpool genetics group came into being in a roundabout way, and here I must digress to explain the background.

\section{The personal story}

As a child I was an ardent butterfly collector, but the urge died away during adolescence only to reappear 20 years later when I spent the last year of the war at a naval hospital in Australia. There the sun shone and the butterflies flew and back it all came. Settling in Liverpool in $1946 \mathrm{I}$ found a way of making butterflies mate ('hand-pairing'1) and this led to an interest in hybridisation and then to genetics.

Next I had a lucky break, meeting (in answer to an advertisement in an entomological paper) a young ex RAF geneticist working in EB Ford's department in Oxford-PM Sheppard. We decided to collaborate, firstly on the genetics of hybrids and later to study the evolution of mimicry in tropical butterflies. The work prospered by correspondence, but in the 1950s there was a vacancy for a lecturer in genetics at the University of Liverpool. Philip asked me about this, but, knowing a negative baby when I saw one, I was discouraging and said I thought Liverpool might not suit him. Three weeks later I had a telephone call asking for more information and I knew then that the fish was hooked. He came in 1956 and we collaborated for 20 years, I becoming professor of medicine, and he professor of genetics until he died of leukaemia in 1976.

Soon after his arrival in Liverpool an episode that I remember well was when, motoring down to the Norfolk Broads to look at the swallowtails, I asked him how I could apply my small but increasing knowledge of genetics to medicine. 'Blood groups' he said, and blood groups it was.

\section{Early papers}

First came work on blood group $\mathrm{O}$ and duodenal ulcer; we disturbed the establishment with a paper that showed that the association disappeared when siblings were used as controls, ${ }^{2}$ and later we shot down a paper from the United States ${ }^{3}$ that claimed a staggering association between duodenal ulcer and $R_{1} R_{2}$ groups and the $M N$ system, and which had been much acclaimed at the International Congress of Human Genetics in Rome. I had a slight feeling that the findings were too good to be true, and when I showed the paper to our chief technician, Mr WTA Donohoe, he smiled and said: 'Sir' (remember, it was 30 years ago) 'this is a transfusion effect' and when we took patients with ulcers who were not admitted to hospital and whose lesions had not bled the association completely disappeared. ${ }^{4}$

\section{The approach to $\mathbf{R h}$}

It was, however, butterfly mimicry that led to an interest in $\mathrm{Rh}$ blood groups, because the method of inheritance of $\mathrm{Rh}$ and of the mimetic patterns was rather similar. $\mathrm{Rh}$ had three loci (on chromosome 1) $\mathrm{Dd}, \mathrm{Cc}$, and Ee, with supposed crossing over to account for the rarer genotypes. The butterflies, too, had a series of genes on the same chromosome 
('linked genes'), usually inherited as a unit (a supergene), and we found occasional crossing over giving rise to the rarer patterns. ${ }^{5}$ Another parallel was in genetic interactions between the $\mathrm{Rh}$ and the $\mathrm{ABO}$ systems (ABO incompatibility protects) and sex in the butterflies (only the females have the mimetic patterns).

\section{A natural protective mechanism}

And so to the protection against $\mathrm{Rh}$ immunisation afforded by $\mathrm{ABO}$ incompatibility between mother and fetus. Levine had made the observation that among $\mathrm{Rh}$ negative mothers who had produced rhesus babies the incidence of $\mathrm{ABO}$ incompatible matings (for example, mother $\mathrm{O}$ and father $\mathrm{A}$ ) was lower than expected. ${ }^{6}$ Following this, Race and Sanger suggested that $\mathrm{ABO}$ incompatibility as between mother and fetus might actually be protective, the naturally occurring anti-A or anti-B eliminating the fetal cells before they had time to stimulate the production of rhesus antibodies. ${ }^{7}$ The experimental work of Stern et al supported this hypothesis ${ }^{8}$; they injected $R h$ positive blood into $R h$ negative male volunteers and noted that much higher titres of anti-D were obtained when compatible blood was injected than when incompatible blood was injected.

It must be remembered that in an $\mathrm{ABO}$ incompatible mating the baby may be compatible, for example, a group $\mathrm{O}$ woman married to a man who typed as group $\mathrm{A}$ can produce an $\mathrm{ABO}$ compatible baby as her husband may be heterozygous AO. Nevanlinna and Vainio pursued this line of research by investigating families in which rhesus haemolytic disease had occurred despite ABO incompatibility between mother and father, and they showed that the immunising fetus was indeed always $\mathrm{ABO}$ compatible. ${ }^{9}$ In addition, they showed by a family study that once immunisation had occurred ABO incompatibility no longer protected.

The Liverpool team decided to repeat this work and, after studying 91 rhesus families, arrived at a similar conclusion - with the additional finding that the ratio of $\mathrm{O} X \mathrm{~A}$ to $\mathrm{A} X \mathrm{O}$ mating was $16: 33$, whereas a 1:1 ratio would be expected if no protection existed. ${ }^{10}$

This work was the beginning of Dr Ronald Finn's MD thesis and the team (usually at that time Clarke, Finn, McConnell, and Sheppard, and a little later John Woodrow and Shona Towers) met frequently to discuss results and future plans, and gradually our interest switched to considering the $80 \%$ of $\mathrm{Rh}$ negative women who were $\mathrm{ABO}$ compatible and therefore at risk for $\mathrm{Rh}$ problems if they had a $\mathrm{Rh}$ positive baby. Could there be a way of mimicking the protection afforded by $\mathrm{ABO}$ incompatibility by giving an appropriate rhesus antibody to the mother after delivery? It sounded good, but could the risks of immunisation be assessed more accurately? Providentially, Zipursky et al produced the answer. ${ }^{11}$ They applied the technique of Kleihauer $e t a l$, to detect fetal cells in the maternal circulation. ${ }^{12}$ It therefore became possible to assess the size and timing of those transplacental haemorrhages that caused immunisation, and this became a most important additional part of Ronald Finn's thesis. The team also made the important observations that a transplacental haemorrhage occurred usually at or near delivery, and that the larger it was the greater the risk of the mother becoming immunised. ${ }^{13} 14$

In 1960, as secretary of the Liverpool Medical Institution, I organised a symposium on the genetic work being carried out in the department of medicine and Ronald Finn was naturally allotted ' $R h$ '. I summarised what he said and sent it to the Lancet, and it was published three weeks after the meeting, on 5 March $1960 .{ }^{15}$ The following is an extract:

\begin{abstract}
'Using a modification of the Zipursky method for the detection of foetal red cells, Dr. Finn had investigated the blood of 50 mothers within 72 hours of delivery. Foetal cells were found in about a third of the compatible matings, but were never found in incompatible matings. This finding further supported the hypothesis that $\mathrm{ABO}$ incompatibility is protective.

Dr. Finn tentatively suggested that it might be possible to destroy any foetal red cells found in the maternal circulation following delivery by means of a suitable antibody. If successful, this would prevent the development of erythroblastosis, so mimicking the natural protection afforded by ABO incompatibility.'
\end{abstract}

At this time no one worried about publishing abstracts that had not been out to referees-it never crossed my mind-all we wanted was priority over the workers in the United States who were on our tails. ${ }^{16}$

\section{Trials in volunteers}

And so to trying out a 'suitable antibody' in real life. But first, was the research ethical?

In the 1960s there were no ethics committees, but we each had a conscience (I have never seen the word in an ethics committee report). We took advice from people like Robert Race and William Maycock. They both thought that our experimental approach, first of all in men, was correct and that we 


\section{Clarke}

should have little difficulty in finding volunteers because if the prophylaxis was successful the benefits were obviously going to be great. Dermot Lehane, our Irish Roman Catholic Blood Transfusion Director, excelled with the volunteers. Within a short time we had our $40 \mathrm{Rh}$ negative men from the Liverpool Police Force-'Men of Merseyside mothers-to-be' as the Liverpool Daily Post called them. Dermot explained to them every possible risk, including leukaemia from the tagged $\mathrm{Rh}$ positive red cells, but to a man they replied (and this really dates us), 'Doctor, we trust you'. Compensation was not mentioned, but Dermot knew how to deal with a minor injection reaction and simply asked, 'How long were you off work, and what do we owe you?' The money was released from a top drawer in Dermot's desk-no forms were needed and we had no problems.

Table 1 Percentage of cells labelled with ${ }^{51}$ Cr remaining at various times after injection

\begin{tabular}{|c|c|c|c|}
\hline Volunteers & 2 Days & 5 Days & 14 Days \\
\hline Unprotected & $\begin{array}{r}106 \\
94 \\
98\end{array}$ & $\begin{array}{l}88 \\
85 \\
87\end{array}$ & $\begin{array}{l}69 \\
67 \\
77\end{array}$ \\
\hline Anti-D given & $\begin{array}{l}48 \\
40 \\
13\end{array}$ & $\begin{array}{r}33 \\
30 \\
6\end{array}$ & $\begin{array}{l}22 \\
21 \\
4 \cdot 6\end{array}$ \\
\hline
\end{tabular}

From Finn $e a{ }^{13}$ reprinted by permission of the publisher.
The anti-D serum that we decided to use was of the complete type and had a titre with the donor's cells in saline of $1 / 64$. The injection was $10 \mathrm{ml}$ given intravenously. ${ }^{13}$ It was Robert Race who advised us to give the 19S because it was this type of antibody that was thought to be protective in ABO incompatibility. Table 1 shows the clearance values in the six volunteers and it will be seen that about $60 \%$ of the cells were removed. We waited anxiously and then-to our extreme disappointment-immune antibody production was not suppressed, and there was even a hint that it was enhanced, and our detractors said 'We told you so'. But our mourning was short lived, for even while our 1961 paper $^{13}$ was still being written, Ruth Sanger came back from the United States with the news that Kurt Stern and Maya Berger had found that, when Rh negative recipients were injected with $\mathrm{Rh}$ positive $A B O$ compatible red cells that had previously been coated with $7 \mathrm{~S}$ antibody, in vitro, they did not become sensitised to Rh even after repeated exposure to the antigen. ${ }^{8}$ We immediately tried this out in our volunteers and found that using 35 to $50 \mathrm{ml}$ of plasma containing predominantly incomplete $\mathrm{Rh}$ antibody, three out of 21 'treated' men developed immune antibody compared with 11 out of 21 controls $(p=0 \cdot 02) .{ }^{14}$

These and similar experiments suggested that to prevent immunisation it was necessary to clear about $95 \%$ of the injected $\mathrm{Rh}$ positive cells within 24 hours, and that the best results were obtained with exclusively $7 \mathrm{~S}$ anti-D antibody, and much more

Table 2 Combined results from various centres. Immune antibody results six months and later in controls and after injection of anti-D gammaglobulin

\begin{tabular}{|c|c|c|c|c|c|c|c|c|}
\hline & \multicolumn{4}{|c|}{ Control } & \multicolumn{3}{|c|}{ Treated } & \multirow{2}{*}{$\begin{array}{l}\text { Total } \\
\text { in } \\
\text { study }\end{array}$} \\
\hline & Total & Immunised & $\begin{array}{l}\text { Not } \\
\text { Immunised }\end{array}$ & $\begin{array}{l}\% \\
\text { Immunised }\end{array}$ & Total & Immunised & $\begin{array}{l}\text { Not } \\
\text { Immunised }\end{array}$ & \\
\hline Liverpool group (first trial) & 136 & 29 & 107 & 21 & 131 & 19 & 130 & 267 \\
\hline Germany* & 76 & 3 & 73 & 4 & 76 & 0 & 76 & 152 \\
\hline Columbia, New York† & 113 & 14 & 99 & 12 & 163 & 0 & 163 & 276 \\
\hline Long Beach, California $\ddagger$ & 176 & 21 & 155 & 12 & 176 & 0 & 176 & 352 \\
\hline Cornell, New York§ & 58 & 5 & 53 & 9 & 41 & 0 & 41 & 99 \\
\hline Edinburgh\| & 40 & 3 & 37 & 8 & 41 & 0 & 41 & 81 \\
\hline Totals & 559 & 75 & 524 & 13 & 628 & 1 & 627 & 1227 \\
\hline
\end{tabular}

*Schneider and Preisler ${ }^{20}$ and Schneider (personal communication).

$\dagger \ddagger \S \|$ Robertson (personal communication).

TThough there is no doubt about the complete failure in this case, it may be instructive. The patient developed a sharp local reaction to the anti-D gammaglobulin, and we then learnt that she had received early in pregnancy a prophylactic dose of antirubella gammaglobulin. Whether this has any bearing on the failure is uncertain.

From Clarke ${ }^{19}$ reprinted by permission of the publisher. 
conveniently and safely (no risk of jaundice) with $7 \mathrm{~S}$ anti-D gammaglobulin, given intramuscularly into the deltoid muscle, rather than with plasma. ${ }^{16}$

The next step was to see if similar results were obtained in $\mathrm{Rh}$ negative, postmenopausal women, and this was indeed the case. Success was now in the air and trials of the prophylaxis were taken up by other countries with similar results. This was most encouraging and a period of great international cooperation followed.

\section{Clinical trials}

In May 1964 we decided to give, within 48 hours of delivery, $5 \mathrm{ml}$ of gammaglobulin containing incomplete anti-D, usually with a titre of between $1 / 1280$ and $1 / 4096$ in albumin with $R_{2} r$ cells (later ${ }^{17}$ $1 \mathrm{ml}$ was shown to be sufficient). This was given intramuscularly to alternate primiparous women in whom the Kleihauer fetal cell score was 5 or more (the 'high risk' trial) and we decided to analyse this trial when about 70 controls and 70 treated women had been followed up for about six months. The results were highly satisfactory. Of the 78 treated, none had definitely produced immune antibody, whereas 19 of the 78 controls had done so. ${ }^{18} 19$ Similar trials (not always restricted to primiparous women and to high risk cases-fetal cell score over 5) were carried out in Germany, ${ }^{20}$ the United States, and Scotland, and table 2 shows the overall results, which were excellent. ${ }^{18}$

There was always the possibility, however, that the prophylactic anti-D was only masking immunisation, and that in the next pregnancy the treated woman would produce overt antibody and catch up with the controls. The data in table 3 show that this was not the case. ${ }^{19}$
The result of the Liverpool 'low risk' trial ${ }^{21}$ makes an interesting comparison with the final outcome of the 'high risk' one. Although the results of treatment in the low risk trial were good, the incidence of immunisation in the second $\mathrm{Rh}$ positive pregnancy was slightly (but not significantly) higher than in the high risk trial. The reason for this is probably that 'primed' mothers are more likely to get into the low risk trial because the number of fetal cells may be low, or even zero, because of concealed antibody that eliminates them. This may also be responsible for most of the failures of anti-D prophylaxis (see table 4).

In those centres where antenatal anti-D is given at 28 and 34 weeks as well as postnatally, this trouble has been circumvented and the incidence of maternal immunisation is considerably reduced. ${ }^{22}$ This entails obtaining much more gammaglobulin, however, and the injections can be wasted as the fetus is not usually grouped in utero and the dose is sometimes given when the child is $\mathrm{Rh}$ negative. A good compromise would be to give antenatal anti-D in first pregnancies because these women are unlikely to have been 'primed' already and it would mean therefore that a $\mathrm{Rh}$ negative woman could probably have at least two babies free of the disease.

Between the successful initial clinical trials and the introduction of routine anti-D by the DHSS in 1970 there were a number of general comments and leading articles on the subject. For example, Jewkes et al in The Sources of Invention give an accurate account of how it all began, but add a most interesting sideline, which is worth repeating ${ }^{23}$ :

'An unusually interesting case of individual initiative was revealed in 1967 when an American doctor, Eugene Hamilton of St. Louis, stood up at one of

Table 3 Combined results: subsequent pregnancies (all centres) up to June 1967, Rh positive ABO compatible infants

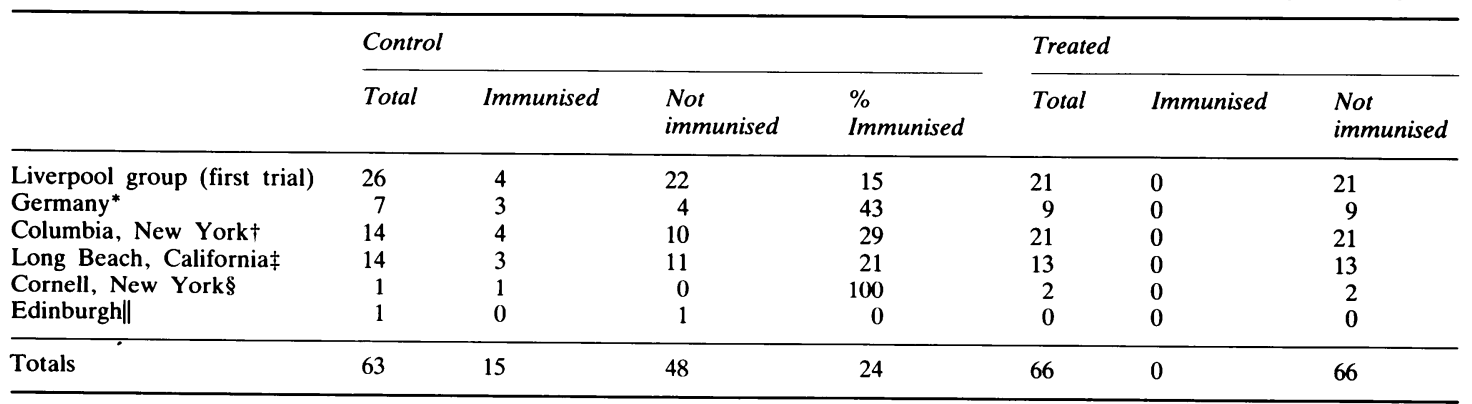

${ }^{*}$ Schneider and Preisler ${ }^{20}$ and Schneider (personal communication).

$\dagger \ddagger \S \|$ Robertson (personal communication).

From Clarke, ${ }^{19}$ reprinted by permission of the publisher. 


\section{Clarke}

Dr. Gorman's lectures and announced that he had started clinical trials in April 1962. He had read the B.M.J. article of May $1961^{(13)}$ giving the first results of the Liverpool workers, and had been impressed with the logic of the approach. He carefully prepared his own plasma from $\mathrm{Rh}$ negative mothers who were severely sensitised and had delivered stillborn foetuses but had no history of hepatitis or other communicable disease. Unknown to other workers in the field, he had for five years given protection with successful results to three times as many mothers as any other of the clinical trials, thus doubling the world figures of proven effectiveness of the treatment'.

Bruce Chown wrote in a leader in the Canadian Medical Association Journal in 1967 'In less than 30 years our understanding of rhesus haemolytic disease of the newborn has run full cycle from hypothesis to prevention'. ${ }^{24}$ The Australians were quick to decide that treatment should be carried out nationwide (see two leading articles in the Medical Journal of Australia in 1967 and 1969). ${ }^{25} 26$ The
Germans, Finns, Swedes, and Icelanders were early in the field, and even behind what then really was an iron curtain, the Hungarians in particular and the Muscovites and Bulgarians embarked on the treatment.

For all this international collaboration and parallel work it was necessary to standardise the anti-D gammaglobulin, as described in the 1967 report of the WHO meeting about prophylaxis in Geneva. ${ }^{27}$ There Hughes-Jones made a great contribution by describing a method that gave more accurate information about the efficiency of an anti-D antibody than did the titre. ${ }^{28}$ This method determined the concentration in $\mu \mathrm{g} / \mathrm{ml}$ and the value of the equilibrium constant of any particular anti-D. The equilibrium constant influences the amount of antibody that is required in the plasma to give a similar concentration of anti-D bound to the red cells. Thus with $1 \mathrm{ml}$ of red cells present in the circulation, 21 times as much of a weakly binding antibody was required compared with the strongly binding antibody. When there are $400 \mathrm{ml}$ of cells in the circula-

Table 4 Classification of deaths, registered by the OPCS as due to haemolytic disease of the fetus or newborn, 1977-87

Categories 1-4 (deaths due to anti-D)

1 Mother believed to have been immunised by a pregnancy following which she was not given an injection of anti-Rh Ig-category divided into:

la immunising pregnancy occurred before 1970 when anti-Rh Ig not widely available

$1 \mathrm{~b}$ immunising pregnancy occurred from 1970 onwards

2 Immunised during first pregnancy (anti-D detected during, or within 7 days following, first pregnancy

3 Immunised despite having been given anti-Rh $\mathrm{Ig}$ after one or more previous pregnancies (that is, failure of prophylaxis)

4 Immunised to $D$ by blood transfusion

Nos in categories 1-4, 1977-1987

\begin{tabular}{|c|c|c|c|c|c|c|c|c|c|c|c|}
\hline Category & 1977 & 1978 & 1979 & 1980 & 1981 & 1982 & 1983 & 1984 & 1985 & 1986 & 1987 \\
\hline $1 \mathrm{a}$ & 53 & 40 & 40 & 31 & 14 & 17 & 4 & 1 & 5 & 8 & 1 \\
\hline $1 b$ & 32 & 28 & 24 & 23 & 12 & 16 & 12 & 11 & 11 & 9 & 9 \\
\hline 2 & 12 & 11 & 10 & 6 & 6 & 5 & 8 & 3 & 9 & 8 & 7 \\
\hline 3 & 9 & 7 & 12 & 11 & 9 & 6 & 9 & 9 & 8 & 5 & 10 \\
\hline 4 & 0 & 2 & 1 & 1 & 0 & 0 & 1 & 1 & 0 & 0 & 0 \\
\hline Total & 106 & 88 & 87 & 72 & 41 & 44 & 34 & 25 & 33 & 30 & 27 \\
\hline $\begin{array}{l}\text { Per } \\
100000 \\
\text { births }\end{array}$ & 18.4 & $14 \cdot 6$ & $13 \cdot 5$ & $10 \cdot 9$ & $6 \cdot 4$ & 7.0 & $5 \cdot 4$ & $3 \cdot 9$ & $5 \cdot 0$ & $4 \cdot 5$ & $3 \cdot 9$ \\
\hline
\end{tabular}

Category 5 Haemolytic disease due to an antibody other than anti-D (anti-c, anti-Kell, etc)

Category 6 Death not due to haemolytic disease

Nos in categories 5 and 6

\begin{tabular}{|c|c|c|c|c|c|c|c|c|c|c|}
\hline 1977 & 1978 & 1979 & 1980 & 1981 & 1982 & 1983 & 1984 & 1985 & 1986 & 1987 \\
\hline Category 54 & 3 & 3 & 4 & 3 & 4 & 4 & 5 & 4 & 4 & 0 \\
\hline Category $6 \quad 45$ & 49 & 21 & 27 & 13 & 19 & 17 & 19 & 15 & 18 & 8 \\
\hline $\begin{array}{c}\text { Total deaths regi } \\
155\end{array}$ & $\begin{array}{c}d \text { by } t h \\
140\end{array}$ & $\begin{array}{l}\text { CS as } \\
111\end{array}$ & $\begin{array}{l}\text { to hae } \\
103\end{array}$ & $\begin{array}{l}\text { tic dis } \\
57\end{array}$ & 67 & 55 & 49 & 52 & 52 & 35 \\
\hline
\end{tabular}


tion, only three times as much weakly binding antibody is required as of the strongly binding one.

\section{An 11 year follow up of rhesus deaths in England and Wales, 1977-87}

In 1977 the Royal College of Physicians set up its Research Unit and I was the first Director. One of the early projects was to 'audit' the state of rhesus immunisation and with Professor PL Mollison's help we looked year by year at the number of deaths from rhesus haemolytic disease of the newborn (table 4) to find out how and when the mother had become immunised. ${ }^{29}$ The Registrar General kindly supplied us with the death or stillbirth certificates for all the infants certified as having died from haemolytic disease of the newborn. In each case we then wrote to the obstetrician who had been in clinical charge of the mother to ask for permission to borrow the notes. This was always given, though it meant a few journeys when the notes were not allowed to leave the hospital.

Over the period, registered deaths and stillbirths from haemolytic disease of the newborn fell by more than $70 \%$, but this fall occurred mainly between 1977 and 1983 and there has been little change since then. Table 4 shows that this is mainly because deaths in categories 2 and 3 have remained constant. These categories include all cases in which postnatal administration could have been of no avail, either because the woman formed anti-D during her first pregnancy (category 2) or because she became immunised despite being given anti-Rh IgG postnatally (category 3 ) and here she was probably 'primed' (see low risk trial, above).

Category 6 shows that over the period the number of deaths falsely registered as being caused by haemolytic disease fell substantially and progressively. This fall was evidently caused by the dialogue with the office of Population Censuses and Surveys (OPCS) stimulated by this survey. The small number of deaths (8) in 1987 falsely registered may be contrasted with the figure of 45 in 1977.

The figure shows some other data graphically. Firstly, whereas between 1977 and 1980 almost twice as many of the infants were born dead as were born alive, from then on the numbers were about equal. This change was undoubtedly partly the result of the great advances in intrauterine treatment of haemolytic disease, so that hydropic fetuses that would previously have died in utero were then kept alivefor example, by direct intravascular exchange transfusion. ${ }^{30}$ The difference must also be partly a result of the advances in the management of premature infants so that pregnancies can be

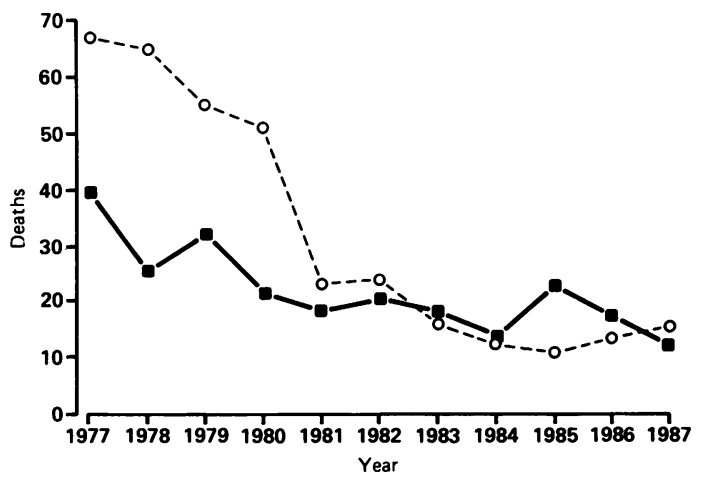

Figure Number of deaths from rhesus (D) haemolytic disease from 1977-1987. Stillbirths $\bigcirc-0$, children born alive (Figure reproduced by courtesy of the editor of the Journal of the Royal College of Physicians of London. ${ }^{29}$ )

terminated earlier with a good chance of having a viable fetus.

In this connection it is of interest that the numbers in category 5 changed little in the years 1977 to 1986 , whereas one might have expected that there would be an increasing tendency for infants to have been rescued by better obstetric care. The numbers are small, however, but although the figure for 1987 signalled a downward trend, there were three cases of anti-c immunisation in 1988 (unpublished observations). About two thirds of the cases in category 5 were due to anti-c. It has been estimated that about one third of women found to have anti-c during pregnancy have been immunised by an earlier $\mathrm{Rh}$ positive (D) transfusion, positive for $\mathrm{c}$, they themselves being $C$. These cases could be prevented by ensuring that $D$ positive $c$ negative women who had not yet reached the menopause were transfused only with c negative blood. Such blood is readily available from blood transfusion centres.

The fact that stillbirths occurring before the 28th week of pregnancy are not registered means that the OPCS figures and ours underestimate the true mortality for haemolytic disease of the fetus. We previously concluded that our figures might only represent two thirds of the total fetal loss from haemolytic disease. The increasing success of treating severe cases in utero as early as the 20th week, however, implies that the underestimate may be becoming smaller.

It will be interesting to see what the future holds and we plan to continue the survey in Liverpool with the help of Professor POD Pharoah and Dr Ruth Hussey in the department of community health. 


\section{Envoi}

The Liverpool work is a good example of research starting as 'useless' (our butterflies would certainly not have satisfied 1989 medical audit) but in fact paying off later. ${ }^{31}$ It could never have been planned, but we were careful to get expert advice as we went along, and it was encouraging that so many centres in different parts of the world took up the work and kept in close touch so that we knew that our results were repeatable. Nothing in biology is $100 \%$ effective, and it is obvious that we have to accept some failures with anti-D, but these are of interest and explicable by the quite unexpected fact that the high risk trial gave better results than the low risk one. Treasure your contradictions!

\section{References}

${ }^{1}$ Clarke CA. Hand pairing of Papilio machaon in February. Entomologist's Record 1952;64:98-100.

2 Clarke CA, Edwards JW, Haddock DRW, Howel-Evans AW, McConnell RB, Sheppard PM. ABO blood groups and secretor character in duodenal ulcer: population and sibship studies. Br Med J 1956;ii:725-31.

3 Buckwalter JA, Tweed GV. The rhesus and MN blood groups and disease. JAMA 1962;179:479-85.

${ }^{4}$ Clarke CA, Donohoe WTA, McConnell RB, Martindale JH, Sheppard PM. Blood groups and disease: previous transfusion as a potential source of error in blood typing. $\mathrm{Br} \mathrm{Med} J$ 1962;i:1734-6.

5 Clarke CA, Sheppard PM. Further studies on the genetics of the mimetic butterfly Papilio memnon L. Philos Trans $R$ Soc Lond (Biol) 1971;263:35-70.

6 Levine P. Serological factors as possible causes in spontaneous abortions. J Hered 1943;34:71-80.

7 Race RR, Sanger R. Blood groups in man. 1st ed. Oxford: Blackwell, 1950:234-6.

${ }^{8}$ Stern K, Goodman HS, Berger M. Experimental isoimmunization to hemoantigens in man. J Immunol 1961;87:189-98.

9 Nevanlinna HR, Vainio T. The influence of mother-child ABO incompatibility on Rh immunisation. Vox Sang 1956;1:26-34.

10 Clarke CA, Finn R, McConnell RB, Sheppard PM. The protection afforded by $\mathrm{ABO}$ incompatibility against erythroblastosis due to rhesus anti-D. Int Arch Allergy Appl Immunol 1958;13:380.

11 Zipursky A, Hull A, White FD, Israels LG. Foetal erythrocytes in the maternal circulation. Lancet 1959;i:451-2.

12 Kleihauer E, Braun H, Betke K. Demonstration von fetalem
Hämoglobin in den Erythrocyten eines Blutausstrichs. Klin Wochenschr 1957;35:637-8.

13 Finn R, Clarke CA, Donohoe WTA, et al. Experimental studies on the prevention of $\mathrm{Rh}$ haemolytic disease. $\mathrm{Br}$ Med $J$ $1961 ; \mathbf{i}: 1486-90$.

14 Clarke CA, Donohoe WTA, McConnell RB, et al. Further experimental studies on the prevention of $\mathrm{Rh}$ haemolytic disease. Br Med J 1963;i:979-84.

${ }^{15}$ Finn R. Erythroblastosis. Lancet 1960;i:526.

16 Freda VJ, Gorman JG, Pollack W. Successful prevention of experimental $\mathrm{Rh}$ sensitization in man with an anti- $\mathrm{Rh}$ gamma $_{2}-$ globulin antibody preparation. Transfusion 1964;4:26-32.

17 Report of a Working Party of the Medical Research Council. Controlled trial of various anti-D dosages in suppression of $\mathrm{Rh}$ sensitisation following pregnancy. $\mathrm{Br}$ Med $J$ 1974;ii:75-80.

18 A Combined Study from Centres in England and Baltimore. Prevention of $\mathrm{Rh}$ haemolytic disease: results of the clinical trial. Br Med J 1966;ii:907-14.

19 Clarke CA. Prevention of Rh haemolytic disease. Br Med J 1967;iv:7-12.

20 Schneider VJ, Preisler O. Prevention of Rh sensitization from fetomaternal microtransfusion. Obstet Gynecol 1966;28:615-21.

21 Woodrow JC, Clarke CA, McConnell RB, Towers SH, Donohoe WTA. Prevention of Rh haemolytic disease: results of the Liverpool 'low risk' clinical trial. Br Med J 1971;ii:610-2.

22 Tovey LAD, Townley A, Stevenson BJ, Taverner J. The Yorkshire antenatal anti-D immunoglobulin trial in primigravidae. Lancet 1983;ii:244-9.

23 Jewkes J, Sawers D, Stillerman R. The sources of invention. 2nd ed. London: Macmillan, 1969:348-51.

24 Chown B. Prevention of Rh haemolytic disease. Can Med Assoc J 1967;97:1294-6.

25 Anonymous. Prevention of Rh haemolytic disease. Med J Aust 1967;2:261-2.

26 Anonymous. Prevention of Rh haemolytic disease. Med J Aust 1969;1:1035-6.

27 WHO Memorandum. The suppression of Rh immunisation by passively administered human immunoglobulin (IgG) anti-D (anti-Rh ${ }^{\circ}$ ). Bull WHO 1967;36:467-74.

28 Hughes-Jones NC. The estimation of the concentration and equilibrium constant of anti-D. Immunology 1967;12:565-71.

29 Clarke CA, Mollison PL. Deaths from Rh haemolytic disease of the fetus and newborn 1977 to 1987. J R Coll Physicians Lond 1989;23:181-4.

30 Grannum PA, Copel JA, Plaxe SC, Scioscia AL, Hobbins JC. In utero exchange transfusion by direct intravascular injection in severe erythroblastosis fetalis. $N$ Engl J Med 1986;314:1431-4.

${ }^{31}$ Clarke CA, ed. Rhesus haemolytic disease, selected papers and extracts, with commentaries. Lancaster: MTP, 1975.

Correspondence to Sir Cyril Clarke, Department of Genetics and Microbiology, University of Liverpool, PO Box 147, Liverpool L69 3BX. 